PRIMANOMICS : JURNAL EKONOMI DAN BISNIS - VOL. 18. NO. 2 (2020)

Versi Online Tersedia di : https://jurnal.ubd.ac.id/index.php/ds

| 1412-632X (Cetak) | 2614-6789 (Online) |

\title{
DYNAMIC CAPABILITIES EROSION IN INDONESIA'S RETAIL INDUSTRY: CONSUMERS' PERSPECTIVE ON MATAHARI DEPARTMENT STORE
}

\author{
Riveria Sari $\left.{ }^{1}\right)$ \\ Akademi Teknik Informatika Tunas Bangsa, Surabaya, Indonesia \\ (riveriasari@gmail.com) \\ Ferri Woejaya2) \\ Universitas Ciputra, Surabaya, Indonesia \\ (ferriwoejaya@gmail.com $)^{2)}$ \\ Teofilus \\ Universitas Ciputra, Surabaya, Indonesia \\ (teofilus@ciputra.ac.id) ${ }^{3}$ )
}

\begin{abstract}
:
This research was conducted to analyze the effect of dynamic capabilities erosion on firm's survival according to consumers' perspective, using sensing erosion, seizing erosion, and reconfiguring erosion as the independent variables $(X)$ and firm survival as the dependent variable (Y). This research uses quantitative research methods with data processing using SPSS. Data collection was carried out by distributing questionnaires online through Google form to 500 student respondents who had visited Matahari Department Store in Indonesia. Sampling is done by purposive sampling technique. The questionnaires that qualify to be analyzed are 158 questionnaires. The result of data processing shows that the effect of the independent variable on the dependent variable is $40.3 \%$. The results of this study is according to consumers' perspective, sensing erosion, seizing erosion, and reconfiguring erosion affect firm survival.
\end{abstract}

Keywords: dynamic capabilities, firm survival, consumer perspective. 


\section{INTRODUCTION}

In the recent years, the performance of retail industry in Indonesia has been decreasing. Based on data from Brand Finance Indonesia, retail industry decreased about 21.5\% anually in average rank from 2013 to 2019 (brandfinance.com). Rank determined by Brand Finance Indonesia is based on net profit of the firms. In 2016 there was a significant decrease in rank, which was $57.5 \%$ in the retail industry. The decrease in 2017 was only around $2.7 \%$. Retail industry is a business sector that deals with retail sales whereby it includes all activities involving the sales of goods or services to be utilized by end consumers for personal use (Kotler, 2012). Firms in Indonesia engaged in the retail industry, specifically in the field of department store are Metro, Ramayana, and Matahari Department Store.

Matahari Department Store is one of the biggest and oldest company engaged in the retail industry sector, specifically department store in Indonesia, which experienced decrease in performance in the recent years (www.investasi.matahari.com). The decrease experienced by Matahari Department Store in year 2017 was recorded as 1.2\% (annual report Matahari Department Store 2017). Net profit for Matahari Department Store decreased in 2018 by about $42 \%$ to $\mathrm{Rp} 1.1$ triliun (annual report Matahari Department Store 2018). This is linked to the decrease in consumers' purchasing power and the lack of sales performance in Matahari Department Store, which resulted in performance erosion.

This was supported by the data from Matahari Department Store that shows the low employee turnover of $11.46 \%$ from the total of $16.2 \%$ in the retail industry in Indonesia. Low employee turnover indicates that there are many people that have worked for a long period of time in Matahari Department Store, therefore it would result in decrease in sensing, seizing and reconfiguring capabilities sehingga (Rahmandad \& Repenning, 2015). In order to overcome the erosion, Matahari Department Store took several actions, such as (1) increase product variance, by focusing on involving additional exclusive fashion brands that can operate in various specific and independent stalls or can also be placed in Matahari stalls, (2) create more attractive and interactive shopping experience for the customers, (3) expand the network of Matahari stalls by opening 4-6 new big stalls and a number of stalls intended specifically for the exclusive fashion brands, (4) develop and improve convergence between online and offline operations, (5) increase Matahari logistic capabilities in order to provide solid foundation for the expansion of the distribution channels. Firms' ability to overcome the erosion tendency can be linked to the theory suggested by Teece (2007), whcih is that dynamic capability is a firm's ability to adapt with the change in customer, environment, and technology that can be used to produce, expand, improve, and 
protect organization's sustainability (Eisenhardt \& Martin, 2006; Laaksonen \& Peltoniemi, 2018; Teece, Pisano, \& Shuen, 2008). This adaptation process can be done by adjusting the firm's ability to utilize, integrate, reconfigure, obtain, and release resources to match the fundamental changes in the market that creates value through modification process (Eisenhardt \& Martin, 2006). Similar idea was also suggested by Liboni et al., (2016) that stated dynamic capabilities have the aim to maintain firm's sustainability.

In order for dynamic capabilities to be applied satisfactorily and efficiently, 3 capabilities are needed. First, the firm needs to have the capability to sense opportunities and threats (sensing), whereby the firm can feel the changes happening in its environment that requires the firm to follow suit. Second, the firm needs to have the capability to come up with opportunities and ideas to overcome the threat (seizing) that involves maintaining and improving the firm's competency in its resources, technology and assets. Thrid, improving, combining, protecting and configuring the firm's resources (reconfiguring), whereby the firm recombines and reconstruct resources, assets and firm's structure to maintain the organization's competitiveness (Teece, 2007; Eisenhardt \& Martin, 2006; Laaksonen \& Peltoniemi, 2018). It is important to have the capabilities of sensing, seizing and reconfiguring because the firm will always be in a market that changes rapidly (Eisenhardt \& Martin, 2006). When a firm is able to keep on adapting to the changes in trend, lifestyle, market changes, it will yield competitive advantage wfor the firm whereby it will be viewed as value creation by customers (Čirjevskis, 2017; Vargo \& Lusch, 2004), and if the customers see the value creation from the firm, the firm will not experience erosion tendency. The firm's sensitivity in responding to changing environment will be much more efficient if oriented on customer's satisfaction and targeting the market and make decisions based on market mix (McCarthy 1960; Kotler, 1967).

The ability to identify consumer's problem, development of solutions and execution of solution will be adjusted based on the consumers and will make consumers feel as if their needs are fulfilled (Vargo, 2004). The execution of solution can be in the form of tangible or intangible asset, or both, most importantly is how the firm interact with customers to determine a customer's specific need (Normann \& Ramirez, 1993; Vargo \& Lusch, 2004). High sensitivity towards changes in environment (sensing) can help a firm to quickly identify the problem that is happening and so the firm can proceed to the next step, which is to make the right decision (seizing). The next step is reconfiguring, which is the execution of the decision as a result of the seizing that will have impact on the firm's sustainability (Teece, 2007). 
Sensing, seizing and reconfiguring capabilities that are continuously applied can result in a structured work rythm and can become a habit or routine (Eisenhardt \& Martin, 2006; Feldman \& Pentland, 2003; Phillips \& Tracey, 2007). Routine is very good when applied to small firms or firms with young age, since small firms need to have structured habits in order to carry out their business activities (D'aveni, 1989; Monteiro, 2019). On the contrary, routine will become inefficient when applied to big firms as doing the same things over and over will result in monotony in its business activities and would cause erosion to the firms' performance (Rahmandad \& Repenning, 2015). Dynamic capabilities erosion is the decrease in organization's performance caused by the organization's inability to adapt and adjust to the changes happening in the environment (Teece, 2007; Eisenhardt \& Martin, 2006; Winter, 2003).

The organization's inability to sense opportunities, create new opportunity ideas, and regonfigure resources will cause the organization to be unable to maintain its competitive advantage and therefore it would lose in competition in the market (Teece, 2007; Brandon-Jones \& Knoppen, 2018; Kor \& Mahoney, 2005; Moghaddam et al., 2018). In order to avoid dynamic capabilities erosion, firms need to hone its sensing, seizing, and reconfiguring capabilities so that the firm's competitive advantage is preserved and it would give value creation to the customers (Vargo \& Lusch, 2004).

\section{THEORETICAL BACKGROUND Dynamic Capability Erosion}

The theoretical background used in this study is the dynamic capability theory, which is the organization's ability to adapt to the changes in environment, opportunities and technology to maintain its competitiveness through improving, combing, protecting and reconfiguring business with the aim to expand, improve, and protect the organization's sustainability (Eisenhardt \& Martin, 2006; Laaksonen \& Peltoniemi, 2018; Teece, 2007). Dynamic capabilities illustrate how organization overcome problems in its environment through adapting in order to survive (Ammentorp, 1968; Souza, Alves, Macini, Cezarino, \& Liboni, 2017). Dynamic capabilities can create opportunity for value creation through modification (Eisenhardt \& Martin, 2006).

When an organization is unable to utilize its dynamic capabilities, then the organizationn will suffer erosion, or what is called as dynamic capabilities erosion that will cause decrease in organizaiton's performance (Eisenhardt \& Martin, 2006; Laaksonen \& Peltoniemi, 2018; Winter, 2003). Organization's inability to identify opportunity, create opportunity ideas, and reconfigure resources will cause the organization to be unable to maintain its competitive advantage and would therefore lose in the competition in the market (Brandon-Jones \& Knoppen, 2018; Kor \& Mahoney, 2005; Moghaddam, Rustambekov, Weber, \& Azarpanah, 2018; Teece, 2007). 
Dynamic capabilities erosion happens when routinities are interupted and therefore the organization suffers decrease in performance (Rahmandad \& Repenning, 2015). On the contrary, having routines in the organization can prolong its sustainability, especially for organizations with young age ( $\mathrm{D}^{\prime}$ aveni, 1989).

Sensing, seizing and reconfiguring capabilities need to be utilized in a firm in order to have value creation for consumers (Čirjevskis, 2017; Vargo \& Lusch, 2004). Consumer's perspective in viewing this matter is how the firm can respond to the consumer's needs and continuously adapting to the relentless changes in its environment so that consumers would view Matahari Department Store as not having erosion tendency (Normann \& Ramirez, 1993; Teece, 2007; Vargo \& Lusch, 2004).

\section{Sensing Erosion}

Sensing erosion is the firm's inability to learn and sense, filter, shape, and calibrate opportunities. Sensing erosion includes a firm's inabilities to process, collect and analyze market information to learn about the consumers, competitors and resources. When opportunities are missed by the firm, the firm is unable to provide new services, processs and acitivies, and organization needs to seize opportunity through investment. In order to seize opportunities, there needs to be renewal and reconfiguration of organization's ability and investment on technology, tools, and market (Brandon-Jones \& Knoppen, 2018).

\section{Seizing Erosion}

Seizing erosion is a firm's inability to create opportunity ideas in relation to opportunities found in new product, process or service. Seizing erosion happens when the firm is unable to proceed after the sensing. Firm will suffer stagnation when it is unable to create ideas from the existing opportunity.

\section{Reconfiguration Erosion}

Reconfiguring erosion refers to the inability to recombing and reconfigure asset and structure as a form of seizing by the firm. Firm is unable to conduct the process of combining, improving, protecting and reconfiguring business assets that are tangible or intangible, and is therefore unable to maintain its competitive advantage that is indicated by the lack of realization of the new strategy or reconfiguration of its resources, structure and process (Cao, 2015).

\section{Firm Survival}

Sensing, seizing and reconfiguring capabilities need to be utilized in a firm in order to have value creation for consumers (Čirjevskis, 2017; Vargo \& Lusch, 2004). Consumer's perspective in viewing this matter is how the firm can respond to the consumer's needs and continuously adapting to the relentless changes in its environment so that 
consumers would view Matahari Department Store as not having erosion tendency (Normann \& Ramirez, 1993; Teece, 2007; Vargo \& Lusch, 2004).

\section{Research Method}

This research uses quantitative research method, which is a research methodology used to study selected population and sample through collection of primary data (Cooper and Schindler, 2014). This study was conducted systematically and in a structured way with the aim to examine test the pre-determined hypotheses.

Sample is a partial total from the population, and therefore it can represent the whole of the population and can be made as the main data collection source of the study. (Sekaran \& Bougie, 2016). The researcher used purposive sampling technique, which is the selection of sample from population with certain considerations or characteristics (Cooper \& Schindler, 2014). The sample chosen was university students because university students are open minded towards new things and are critical enough in responding to a situation. Researcher took university students in Java Island as sample because majority of Indonesian population is located in Java Island, which is $57.5 \%$ and majority of the population in Indonesia is y generation aged 20-37 years old, which accounts for $33.75 \%$ (www.bps.go.id). Researcher used university students that has visited Matahari Department Store more than 2 times in the last 1 year as the sample.

\section{Data Collection}

This study used primary data whereby the primary data was collected directly by the researcher, and also uses Likert scale in the questionnaire to measure the answers from the respondents. According to (Cooper \& Schindler, 2014), Likert scale is used by respondents to determine how much they agree with a statement or option by choosing one from the available choices. The following is the Likert scale used in this study. The Likert scale ranking used for this study is as follows: (a) score 5 for strongly agree on a statement, (b) score 4 for agree on a statement, (c) score 3 for not sure on a statement, (d) score 2 for disagree on a statement, (e) score 1 for strongly disagree on a statement. Validity test and reliability test were conducted on each of the questionnaire statements. The questionnaire statements used are questionnaire items that have passed the validity test and reliability test. Data processing in this study was obtained by conducting classic assumption tests (normality test, multicollinearity test, and heteroscedasticity test) and multiple linear regression analysis test.

\section{Result and Discussion}

Data collected is analyszed using statistical analysis tool Multiple Regression Analysis (MRA), which is data analysis with more than 1 independent variable (Render, Stair, \& 
Hanna, 2011). This analysis uses 2 independent variables and 1 dependent variable. The following result was obtained:

\section{F-test}

Significance levels of the F-statistic test in the Test Result Table of the three models yielded results of $\leq 0.05$, which is 0.000 , therefore it can be concluded that sensing erosion (X1) variable, Seizing Erosion (X2) and Reconfiguring Erosion (X3) have significant impact on Firm Survival (Y).

\section{t-test}

The table of $t$-test result shows $t$ and sig values of each of the $X$ variables. SSE $\left(X_{1}\right)$ shows calculated $t$ of 3.301 with significance level of 0.003 . Based on the significance level of $<0.05$, it shows that there is partial impact of SSE variable on firm survival. SZE $\left(\mathrm{X}_{2}\right)$ shows calculated $\mathrm{t}$ of 4.610 with significance level of 0.000 . Based on the significance level of $<0.05$, it shows that there is partial impact of SZE variable on firm survival. RCE $\left(X_{3}\right)$ shows calculated $t$ of 4.050 with significance level of 0.000 . Based on the significance level of $<0.05$, it shows that there is partial impact of RCE variable on firm survival.

\section{Correlation Coefficient ( $R$ ) and Determination Coefficient $\left(\mathbf{R}^{2}\right)$ Analysis}

$\mathrm{R}^{2}$ test was conducted to determine how far can the independent variable affect the dependent varaible. The discussion from the correlation coefficient (R) and determination coefficient $\left(R^{2}\right)$ result from the test conducted in this study is that coefficient correlation $(\mathrm{R})$ has the value of 0.635 , which indicates that the relationship between the independent variables which are SSE, SZE and RCE with firm survival erosion does indeed occur. Value of determination coefficient is 0.403 , which means that the effect of independent variables SSE, SZE and RCE on firm survival is $40.3 \%$, and the remaining $59.7 \%$ is explained by other variables not explored in this study. This study has in total 3 dependent variables, and therefore only requires $\mathrm{R}^{2}$ and does not require adjusted $R^{2}$. 
AUTHORS / PRIMANOMICS : JURNAL EKONOMI DAN BISNIS - VOL. 18. NO. 2 (2020)

Table 1: Result of Multiple regression Analysis

\begin{tabular}{lllllllll}
\hline $\begin{array}{l}\text { Mod } \\
\text { el }\end{array}$ & Variable & F & Sig. & $\mathbf{R}$ & $\mathbf{R}^{2}$ & Beta & $\mathbf{t}$ & Sig. \\
\hline & Sensing & & & & & 0.19 & $\mathbf{3 . 3 0}$ & $\mathbf{0 . 0 0 3}$ \\
& Erosion & & & & & 9 & $\mathbf{1}$ & \\
$\mathbf{1}$ & Seizing & 34.70 & 0.00 & 0.63 & 0.40 & 0.33 & $\mathbf{4 . 6 1}$ & $\mathbf{0 . 0 0 0}$ \\
(all) & Erosion & 8 & 0 & 5 & 3 & 2 & $\mathbf{0}$ & \\
& Reconfigure & & & & & 0.29 & $\mathbf{4 . 0 5}$ & $\mathbf{0 . 0 0 0}$ \\
& Erosion & & & & & 6 & $\mathbf{0}$ & \\
\hline
\end{tabular}

Source: Data Processed 


\section{Discussion}

\section{Impact of Sensing Erosion on Firm Survival}

Majority of the sensing erosion indicators fulfill the requirements to reflect sensing erosion variable in this study. This shows that PT Matahari Department Store is facing erosion in the firm's sensing capability in consumers' opinion.

This study shows that there is a significant impact of sensing erosion on firm survival. The significance value of SSE variable is $<0.05$. This shows that in consumer's perspective, PT Matahari Department Store is facing erosion in the firm's sensing capability, which will impact sustainability of PT Matahari Department Store. The result of this study sugests that the firm's inability in sensing opportunities and threats will cause decrease in the firm's performance (Moghaddam, 2018; Vargo, 2004; Winter, 2003). Therefore, the firm needs to improve its sensing capability by completing Matahri with matching facilities such as improving the quality of the call centre and innovate on the products sold. Call centre facility can diminish sensing erosion by seriously responding and accurately respond to customer's complaints, one of which is to give refund for products if there is any damage. Consumer can discover improvement in product innovation through employees' services by explaining the new product innovation and through promotion in consumer social media (uploading photos of Matahari).

\section{Impact of Seizing Erosion on Firm Survival}

Majority of the seizing erosion indicators fulfill the requirements to reflect seizing erosion variable in this study. This shows that PT Matahari Department Store is facing erosion in the firm's seizing capability in consumers' opinion.

This study shows that there is a significant impact of seizing erosion on firm survival. The significance value of SZE variable is $<0.05$. This shows that in consumer's perspective, PT Matahari Department Store is facing erosion in the firm's seizing capability, which will impact sustainability of PT Matahari Department Store. Result of the study suggests that firm's inability to create opportunity ideas and threats will result in decrease in firm's performance (Kor \& Mahoney, 2015; Teece, 2007; Weitzel, 1989).

Therefore, the firm needs to improve its seizing capability by adding the number of partners to cooperate with Matahari Department Store and provide optimum service. Adding the number of partners can reduce seizing erosion through adding payment methods such as installments and cashless payment methods such as GOPAY, DANA and SAKUKU. Optimum service can be achieved through providing excellent service standard, such as giving greeting, salutation and smile, and offer good communication in relation to new and interesting products.

\section{Impact of Reconfiguring Erosion on Firm Survival}

Majority of the reconfiguring erosion indicators fulfill the requirements to reflect reconfiguring erosion variable in this study. This shows that PT Matahari Department 
Store is facing erosion in the firm's reconfiguring capability in consumers' opinion. This study shows that there is a significant impact of reconfiguring erosion on firm survival. The significance value of SZE variable is $<0.05$. This shows that in consumer's perspective, PT Matahari Department Store is facing erosion in the firm's reconfiguring capability, which will impact sustainability of PT Matahari Department Store. The result of this study suggests that the firm's inability to execute the results obtained from seizing will cause decrease in firm's performance (Brandon-Jones \& Knoppen, 2018; Rahmandad \& Repenning, 2015; Teece, 2007). Therefore, the firm needs to improve on its reconfiguring capability through adding the number of merchandise vendors and add value to Matahari Department Store firm. Adding number of merchandise vendor will reduct reconfiguring erosion because consumers will view Matahari as having many brands and product variation, hence consumers can choose based on their desire and subsequently diminish reconfiguring erosion. Adding value to the firm can be done by by providing trending or booming products, through adjusting to the market's taste, especially those aged 17-19 years old, so that consumer will have favorable view on Matahari Department Store.

\section{CONCLUSION AND SUGGESTION Conclusion}

From the result of the study conducted, it can be concluded that dynamic capability is a firm's ability to adapt to the ever-changing environment. However, dynamic capability can face erosion when the firm does not have sensing, seizing and reconfiguring capability.

Sensing erosion is a firm's inability to sense opportunities and threats in the environment around the firm. In consumer's perspective, PT Matahari Department Store is facing sensing erosion, especially in the firm's inability to come up with new products. Therefore, as a competing firm Matahari needs to work on its ability to sense by combining several local brands so that it would create a new innovation by paying more attention to the market's taste. Based on the research result, Matahari Department Store visitors are dominated by women (57\%) and university students aged 17-19 years old (67.1\%) followed aged 20-25 years old (31.6\%). It can be concluded that Matahari needs to provide products that would attract university students aged 17-19's purchase intention and start innovating on products for the other groups.

Seizing erosion is the firm's inability to create opportunity idea as a result from the sensing stage. In consumer's perspective, PT Matahari Department Store is facing seizing erosion, especially in terms of providing promotion and services. Therefore, as a competing firm Matahari needs to work on its seizing ability by giving optimum service and providing interesting promotion such as giveaway which requires uploading certain photos about Matahari on social media.

Reconfiguring erosion is the firm's inability to execute the opportunity ideas obtained from seizing stage. In consumer's perpective, PT Matahari Department Store is facing reconfiguring erosion, especially in terms of product provision. Therefore, as a 
competing firm Matahari needs to work on its reconfiguring ability by providing various brand products and product availability in Matahari Department Store.

If the firm is unable to sense, seize and reconfigure, the firm will face erosion, which is indicated by the decrease in performance, which would threaten the firm's sustainability.

\section{Suggestions}

Based on the result of the research, the following suggestions can be made:

1. PT Matahari Department Store can improve its sensing, seizing and reconfiguring capabilities to improve the firm's performance, especially for managers and employees, this can be done through being more open to new things and consumer's perspective through adding the number of product variations and product availability and providing optimum service.

2. PT Matahari Department Store can add service that ease the consumers when shopping such as customized fashion products and adding credit payment method so that it would provide convenience for consumers when making payments.

3. Future studies can consider developing dynamic capabilities theory and elaborating and investigating further on other variables that affect sensing erosion, seizing erosion and reconfiguring erosion of a firm. Future studies can be better if the scope is not the millennial generation so that the data obtained will be more heterogeneous and broad.

4. Future studies can be better if erosion is further mapped, which one occurs first, whether the erosion happens in the firm internal scope or external scope and whether the erosion occurs in individual level or organizational level.

\section{Biblography}

Ammentorp, W. (1968). Essay Reviews : Organizations in Action, James D. Thompson, New York: McGraw-Hill Book Co., 1967 Organizing Men and Power, Robert T. Golembiewski, Chicago: Rand McNally and Co., 1967. Educational Administration Quarterly, 4(3), 85-89.

Brandon-Jones, A., \& Knoppen, D. (2018). The role of strategic purchasing in dynamic capability development and deployment: A contingency perspective. International Journal of Operations and Production Management, 38(2), 446-473.

Cao, L. (2011). Dynamic capabilities in a turbulent market environment: Empirical evidence from international retailers in China. Journal of Strategic Marketing, 19(5), 455-469.

Čirjevskis, A. (2017). Unbundling dynamic capabilities in successful Asian-Pacific shipping companies. Journal of Asia Business Studies, 11(2), 113-134.

Cooper, D. R., \& Schindler, P. S. (2014). Business Research Methods. In.

D'aveni, R. A. (1989). The Aftermath Of Organizational Decline: A Longitudinal Study Of The Strategic And Managerial Characteristics Of Declining Firms. Academy of Management Journal, 32(3), 577-605.

Eisenhardt, K. M., \& Martin, J. A. (2006). Dynamic Capabilities: What Are They? Dynamic Capabilities: What Are They ? 21(10), 1105-1121.

Englis, P. D., Englis, B. G., Ratinho, T., \& Groen, A. J. (2011). An Ear to the Ground: The Role of the Voice-of-the-Consumer in Firm Survival for Startups. ICBS World 
Conference 2011 "Changes in Perspectives of Global Entrepreneurship and Innovation," 21.

Gujarati, N. D \& Porter, D. C. 2013. Dasar-dasar Ekonometrika. Buku 1 dan Buku 2 Edisi 5. Penerjemah: Raden Carlus Mangunsong. Jakarta: Salemba Empat.

Hair, J. F., Black. W. C., Babin. B. J.; and Anderson. R. E. (2010), Multivariate Data Analysis, 7th ed. Pearson Prentice Hall, New Jersey.

Ho, R. (2006). Handbook Of Univariate And Multivariate Data Analysis And Interpretation With SPSS. In.

Josefy, M. A., Harrison, J. S., Sirmon, D. G., \& Matz Carnes, C. (2017). Living and dying: Synthesizing the literature on firm survival and failure across stages of development. Academy of Management Annals, 11(2), 770-799.

Kor, Y. Y., \& Mahoney, J. T. (2005). How dynamics, management, and governance of resource deployments influence firm-level performance. Strategic Management Journal, 26(5), 489-496.

Kotler, Philip \& Kevin Lane Keller. 2012. Marketing Management (14ethEdition). New Jersey : Prentice-Hall Published

Kotler, P. (1967) Marketing Management: Analysis, Planning, and Control. PrenticeHall, Upper Saddle River.

Laaksonen, O., \& Peltoniemi, M. (2018). The Essence of Dynamic Capabilities and their Measurement. International Journal of Management Reviews, 20(2), 184-205.

Liboni, L.B., Chiappetta, J.C.J., Jabbour, A. and Kannan, D. (2016), “Sustainability as a dynamic organizational capability: a systematic review and a future agenda toward a sustainable transition", Journal ofCleaner Production, Vol. 142, pp. 308-322.

Malhotra, Naresh K., and David F. Birks. (2012). Marketing Research: An Applied Approach 3rd European Edition. Harlow, England: Prentice-Hall.

McCarthy, E. J. (1960). Basic Marketing: A Managerial Approach. Homewood (Illinois): R. D. Irwin.

Moghaddam, K., Rustambekov, E., Weber, T., \& Azarpanah, S. (2018). Transnational entrepreneurship, social networks, and institutional distance. New England Journal of Entrepreneurship, 21(1), 45-64.

Monteiro, G. F. A. (2019). High-growth firms and scale-ups: a review and research agenda. RAUSP Management Journal, 54(1), 96-111.

Normann, Richard and Rafael Ramirez (1993), "From Value Chain to Value Constellation: Designing Interactive Strategy," Har- vard Business Review, 71 (July-August), 65-77.

Phillips, N., \& Tracey, P. (2007). Opportunity recognition, entrepreneurial capabilities and bricolage: Connecting institutional theory and entrepreneurship in strategic organization. Strategic Organization, 5(3), 313-320.

Rahmandad, H., \& Repenning, N. (2015). Business groups in developing capital markets: Towards a complementarity perspective. Strategic Management Journal, 127(1), 12-13.

Render, B., Stair, R. M., \& Hanna, M. E. (2011). Quantitative Analysis for Management. In.

Sekaran, U., \& Bougie, R. (2016). Research Methods For Business. In.

Souza, A. A. A., Alves, M. F. R., Macini, N., Cezarino, L. O., \& Liboni, L. B. (2017). Resilience for sustainability as an eco-capability. International Journal of Climate 
Change Strategies and Management, 9(5), 581-599.

Teece DJ. 2007. Explicating dynamic capabilities: the nature and microfoundations of (sustainable) enter- prise performance. Strategic Management Journal 28(13): 13191350.

Teece, D. J., Pisano, G., \& Shuen, A. (2008). Dynamic capabilities and strategic management. Technological Know-How, Organizational Capabilities, and Strategic Management: Business Strategy and Enterprise Development in Competitive Environments, 18(March), 27-52.

Tucker, L.R., \& MacCallum, R.C. (1997). Exploratory factor analysis.

Vargo, S. L., \& Lusch, R. F. (2004). Evolving to a New Dominant Logic for Marketing. Journal of Marketing, 68(1), 1-17.

Weitzel, W., \& Jonsson, E. (1989). Decline in Organizations: A Literature Integration and Extension. Administrative Science Quarterly, 34(1), 91.

Winter, S. G. (2003). Understanding dynamic capabilities. Strategic Management Journal, 24(10 SPEC ISS.), 991-995.

https:// brandfinance.com// Brand Finance Indonesia. Diakses 2 Oktober 2019

http://www.ramayana.co.id// Annual Report Ramayana 2018. Diakses 11 November 2019

http:/ /investor.matahari.co.id// Annual Reports 2018. Diakses 11 November 2019

http://investor.matahari.co.id// Annual Reports 2017. Diakses 11 November 2019

http://www.investasi.matahari.com// Berita Matahari. Diakses 27 Oktober 2019 